\section{Jubilee of Powered Flight}

OrVILLE WRIGHT's first successful powered flight occurred fifty years ago on December 17, 1903. Man's age-old ambition to fly had culminated in considerable aeronautical activity during the last quarter of the nineteenth century. Ballooning had been well established before this, and there remained the mastery of 'heavier-than-air' flight. Lilienthal and Pilcher had made precarious flights in gliders of various bird-like shapes and had ultimately perished. Octave Chanute, president of the American Society of Civil Engineers and builder of the first bridge over the Missouri, had invented-and flown-the biplane arrangement of the wings of his glider. Lanchester and Langley had flown stable model 'aerodromes', the latter's including steam-powered tandems which were capable of speeds in excess of $30 \mathrm{~m} . \mathrm{p} . \mathrm{h}$. How ever, Langley's man-carrying machine had fallen into the Potomac River immediately after being catapulted from a houseboat on December 8, 1903. This concluded the heartbreaking story of seventeen years of scientific effort by the secretary of the Smithsonian Institution and his associates. It is evident that some of the Wrights' contemporaries were very close to success at that time, but none of them had the Wright brothers' combination of the gifts of scientific appreciation of evidence, design ingenuity and ability to make apparatus with their own hands. They carefully analysed Lilienthal's results and then gave their attention to three problems: the provision of adequate lift with stability, of thrust and of control. They studied the first with a home-made wind tunnel and built their own 12-b.h.p. internal combustion engine. They developed their own propellers and achieved the then remarkable efficiency of 66 per cent. Their wingwarping system of lateral control was a crucial advance upon what had gone before, but it is the overall achievement that these men are best known for. They were mechanics in the best sense of the term.

A special exhibition commemorating the jubilee will be opened at the Science Museum, London, S.W.7, on December 15 and will remain on view for about three months (admission free). Models, books, aeronautical relics and diagrams will be displayed illustrating early contemporary thoughts and ideas on powered flight by a man-carrying machine, and how this was ultimately achieved by the Wright brothers. The National Geographic Magazine of December contains an article on the work of the Wright brothers with several historical photographs.

\section{Natural Philosophy at Edinburgh:}

Prof. M. Born, F.R.S

Prof. Max Born, who has recently retired from the Tait professorship of natural philosophy at the University of Edinburgh, succeeded Sir Charles Darwin in that chair in 1936, when the latter was appointed Master of Christ's College, Cambridge. He had previously been Professor Ordinarius at Göttingen, where he was head of the world-renowned school of theoretical physics, which with Bohr's Institute for Theoretical Physics at Copenhagen played such a large part in the development of the quantum theory and its applications in the period between the two World Wars; while headed by Prof. Born it was, like Bohr's Institute, a place of pilgrimage for all those working in this field of theoretical physics. In 1933 the rising tide of Nazism in Germany drove him to leave Göttingen, and he went to Cambridge as lecturer in the Faculty of Mathematics; he was appointed Stokes lecturer in applied mathematics in 1934, and held this post until his appointiment to Fdinburgh. He was elected a Fellow of the Royal Society in 1939. Both by his own work and through the stimulus, encouragement and help which he gave to others, Prof. Borm has had considerable influence on progress in various branches of theoretical physics, notably in the dynamics of crystal lattices, in quantum theory both in its general aspects and in its applications to particular systems, and latterly in the theory of the structure and properties of liquids.

Prof. N. Kemmer

Prof. N. Kemmer, who succeeded Prof. Born at Edinburgh at the beginning of the current academic year, was, like his predecessor, Stokes lecturer in applied mathematics at Cambridge before his appointment to Edinburgh. He has studied abroad for a considerable period, and holds the degree of D.Phil. of Zurich. He was appointed a lecturer in the Faculty of Mathematics at Cambridge in 1946, and was elected to a fellowship at Trinity College in the same year; he was appointed Stokes lecturer in 1949. He has been a member of the Board of the Faculty of Mathematics, and is interested both in teaching and research in mathematical physics. His main lines of research interest are quantum theory and its applications, especially nuclear theory and, more recently, quantum field theory and quantum electrodynamics. In this field he has been one of the leaders of a vigorous group of investigators at Cambridge, and has had a number of research students working under his direction.

Geology and Mineralogy at Trinity College, Dublin: Dr. W. D. Gill

DR. W. D. GruL has recently been appointed to the chair of geology and mineralogy in Trinity College, Dublin, which became vacant last year on the death of Prof. L. B. Smyth (see Nature, 171, 196 ; 1953). Graduating in 1938 from the University of Leeds with first-class honours in geology, Dr. Gill joined the Attock Oil Co., Burma, and, working as a micro-palæontologist and field geologist, was a member of a small team which discovered many new prospects for oil. Specializing on the Siwalik Series in the Northern Potwar, he also discovered new foraminifera in Eocene formations. He joined the staff of the University of Nottingham in 1948 and became responsible for the development of photogrammetry in the Department of Geology and the establishment of a flourishing school of research on the micropalæontology of the Jurassic and Cretaceous rocks of Lincolnshire and Yorkshire. Using published and original material, Dr. Gill synthesized the structure and mechanism of mountain building in the frontal Himalayas. He takes to Trinity College, Dublin, a great store of new material and an enthusiasm for geological research in every field of the subject, and especially in structural and stratigraphical studies.

Expansion of the Department of Scientific and Industrial Research during 1954-59

THE principal effects of the recent announcement by Sir Ian Heilbron about the future development of the Department of Industrial and Scientific Research (see Nature, December 5, p. 1029) will be to enable the post-war plans of the Department to 